\title{
ONLINE LEARNING GROWS UP-AND HEADS TO LAW SCHOOL
}

\author{
MAX HUFFMAN*
}

\section{INTRODUCTION}

Online education is now in the mainstream. Schools use online teaching methods as early as elementary school and thousands of students across the country pursue their entire high school studies online. ${ }^{1}$ Undergraduate and graduate programs are offered online. ${ }^{2}$ At Indiana University, where I teach, there are nearly fifty undergraduate, graduate, and professional degrees offered entirely online. ${ }^{3}$ An increasing percentage of law students have taken at least one, and some have taken several, online courses before matriculating into the J.D. program. ${ }^{4}$

The legal academy has been slow to catch on. Perhaps wedded to a Langdellian ${ }^{5}$ view of teaching by casebook and Socratic methods, law schools' primary accrediting agency, the American Bar Association ("ABA"), limits opportunities for online learning in law schools. ${ }^{6}$ No student may take courses online in his or her first year and, in the absence of a variance, the maximum number of credits students may take online in a J.D. program is fifteen. ${ }^{7}$ ABAaccredited online law schools are several years away-at least in regards the J.D. degree.

The academy's recalcitrance is a mistake. Online legal education promises reduced costs for students, increased flexibility, a more diverse student population in any one course, degree, or sub-degree program, and improved learning outcomes. Law schools that recognize this opportunity and seize it, paying close attention to learning outcomes and pedagogically sound course design, will earn

* Professor of Law and Faculty Director of Online Programs, Indiana University Robert H. McKinney School of Law. Yvonne Dutton and Doug Jerolimov provided helpful edits and suggestions. Thanks also to Alex Hanauer, Cale Addison Bradford, and their colleagues at the Indiana Law Review and to my colleague on the library faculty, Susan deMaine, for excellent assistance.

1. See, e.g., Connections ACAD., http://www.connectionsacademy.com/ [http://perma. cc/473S-8DXA] (last visited Aug. 26, 2015).

2. See, e.g., Indiana University Online, IND. U., http://online.iu.edu/[http://perma.cc/TF9WFHMY] (last visited Aug. 26, 2015).

3. Id.

4. See id.

5. For more on Christopher Columbus Langdell, see infra Part I.B.

6. Am. Bar Ass'N, 2014-2015 A.B.A. Standards ANd Rules of Procedure for APPROVALOFLAW SCHOOLS 19-20 (2014), available at http://www.americanbar.org/content/dam/ aba/publications/misc/legal_education/Standards/2014_2015_aba_standards_and_rules_of_proc edure_for_approval_of_law_schools_bookmarked.authcheckdam.pdf [http://perma.cc/C97B-H6 9R].

7. Id. at 19. The "first year" restriction is literally a "first 28-credit" restriction. Id.

http://dx.doi.org/10.18060/4806.0061 
a competitive advantage while benefitting their students.

Non-ABA-accredited fully online law schools do exist, primarily in California where state-level accreditation is sufficient to allow graduates to sit for the state bar. ${ }^{8}$ Third-party providers offer online courses to law students by contract with the students' home institutions. ${ }^{9}$ Through a contract with one of those providers, two courses my institution offered online last spring attracted students from three other law schools as well as from my home institution, and at least one student earned credit for a class taken online from a different school.

Traditional law schools are not being left out. At least one law school has been proactive in seeking a variance of ABA limits to allow students to pursue a hybrid on-campus/online degree. ${ }^{10}$ In increasing number law schools are offering enough classes online for students to reach the limit of total allowable online credit hours. Non-J.D. degrees, including L.L.M. degrees and the newer "Master of Jurisprudence" are increasingly available online. ${ }^{11}$ Graduate certificates, usually fifteen-credit sub-degrees, can be offered fully online. ${ }^{12}$

Some terminology: this Article discusses online education, which is a subpart of the general category of distance education. Online teaching is conducted using the Internet and software and hardware developed for Internet communication. Because online teaching postdates the earliest distance education "correspondence courses," understandings of effective pedagogy inform online education in ways that they may not with regard to distance teaching generally. Too many of the benefits (and some of the costs) arise in the unique setting of Internet communication. This article is about online education specifically, although the AB A Standards and some of the authorities cover discuss education generally, ${ }^{13}$ I use the terms interchangeably.

I draw a distinction in this Article between synchronous and asynchronous education. Synchronous means real-time and asynchronous means time-shifted. A variety of options exists for each. Generally, synchronous online courses can be imagined as taking place over a video-conference, perhaps even with one node

8. See Registered Unaccredited Distance-Learning Law Schools in California, ST. B. CALIFORNIA, http://admissions.calbar.ca.gov/Portals/4/documents/Education/ 2015_05_MasterListofUnaccreditedDistanceLearningSchools_R.pdf [http://perma.cc/4CC7-L6B2] (last visited Aug. 26, 2015).

9. See, e.g., Introducing PracticeTrack, WOLTERS KLUwER, https://www.wkpracticetrack. com/ [http://perma.cc/7ZBN-8F2G] (last visited Sept. 29, 2015).

10. ABA Approves Variance Allowing William Mitchell to Offer 'Hybrid' On-Campus/Online J.D. Program, WM. MitChell C. LAw (Dec. 17, 2013), http://web.wmitchell.edu/news/2013/ 12/william-mitchell-to-offer-first-aba-accredited-hybrid-on-campusonline-j-d-program/ [http://perma.cc/4WL8-3GFB].

11. See, e.g., Institute for Consumer Antitrust Studies, LOY. U. CHI. SCH. LAw, http://www. luc.edu/law/centers/antitrust/degreesandcertificates/mjinglobalcompetitionlaw/ [http://perma.cc/C8XM-WC6L] (last visited Sept. 29, 2015).

12. See Am. BAR Ass'N, supra note 6, at v (describing ABA Standards, which only apply to J.D. degrees).

13. See id. at 19-20. 
of the video conference taking place in a real law school classroom with the professor joining the class- "Skyping in"-from a remote office. Generally, asynchronous online courses can be imagined as being conducted through a course website with readings, recorded lectures, and student activities posted for students to access. The professor guides students through the course website using discussion boards and after-the-fact commentary on student assignments and quizzes. The terms "hybrid" and "blended" are used sometimes interchangeably to mean a combination of more than one methodology in the same course, for example, part online, part live instruction. ${ }^{14}$

In this Article, I explore the development, current state, and future of online teaching in U.S. law schools. Part I starts with a brief overview of law school pedagogy, canvassing the excellent historical literature on U.S. legal education beginning in the 1800s. Part II discusses how online learning can improve existing law school pedagogy and serve as a vehicle for other innovations, such as experiential learning, that may be desirable or necessary. Part III considers the experience of my own institution, the Indiana University Robert H. McKinney School of Law, with regard to course design, quality control, and the experience in one recent online course offering.

\section{A Quick Tour of Law School Pedagogy}

This Part begins with a discussion of past and current practices in law school teaching, dating from the 1800 s to the modern day.

\section{A. Law as an Experimental Science: Langdellian Pedagogy}

The original process of teaching law in the United States was an apprenticeship method whereby students articled under the tutelage of an experienced attorney. ${ }^{15}$ Formal law schools were an outgrowth of the apprenticeship system as lawyers particularly skilled in teaching attracted cohorts of apprentices from across the country. ${ }^{16}$ Private schools developed on this model proved superior to fledgling law programs at established universities. In response, rather than developing from scratch, universities found it productive to merge with preexisting private schools across the middle part of the nineteenth century. ${ }^{17}$

1. The Case Method.-Modern law teaching dates to the late nineteenth century. Beginning in 1870, Christopher Columbus Langdell, as Dean of Harvard Law School, implemented in the law school curriculum a teaching method championed by Harvard University President Charles William Eliot. ${ }^{18}$ Eliot's

14. See generally John V. Dempsey \& Richard N. Van Eck, E-Learning and Instructional Design, in Trends and Issues in Instructional Design 281-289 (Robert A. Reiser \& John V. Dempsey eds., 3d ed. 2012).

15. See Robert Stevens, Law School: Legal Education in America From the 1850s TO THE 1980s 3 (1983).

16. Id. at 3-4.

17. Id. at 5 .

18. See Neil Duxbury, Patterns of American Jurisprudence 13-14 (1995); Stevens, 
method, designed for the teaching of chemistry, involved recreating known scientific experiments with a goal of generalizing them. ${ }^{19}$ Langdell's importation of Eliot's methods into law school classrooms probably originated in an attempt to glean from English common law rules of sufficient generality to inform the development of U.S. law. ${ }^{20}$ One of Langdell's early hires, James Barr Ames, popularized law study as an academic discipline. ${ }^{21}$ The Langdellian case method remains the signature pedagogy of U.S. legal instruction. ${ }^{22}$

The Langdellian case method, as normally applied, relies on Socratic dialogue between teacher and student to analyze past authorities and test the reach of those authorities under increasingly removed factual scenarios. ${ }^{23}$ That inductive process of reasoning from the specific (a case) to the general (a range of fact patterns) develops both knowledge of existing rules and student intuition for the application of those rules in untested settings. ${ }^{24}$

The process of question-and-answer in a public setting develops skills, including reasoning under pressure and time constraints, and public speaking. ${ }^{25}$ Those skills have proved over 125 years to be highly relevant to certain sub-parts of the legal profession. Students who excel at the Socratic dialogue and the inductive reasoning process it teaches make excellent judicial clerks, judges, and law professors. Appellate law practice in many courts is nearly identical to Socratic dialogue, with an informed discussion leader (the judge or panel) directing the discussant (the lawyer) through the nuances of a body of law as applied to a particular fact pattern. ${ }^{26}$

The Socratic method of live classroom teaching is less effective at developing lawyering skills that do not rely on giving real-time, under pressure, verbal

supra note 15 , at 35 .

19. Stevens attributes the success of Langdell's methods to Eliot, not Langdell. STEVENS, supra note 15 , at 35 . Eliot was a proselytizer for the scientific method of learning with extensive contacts throughout the academy. $I d$.

20. Id. at 14 .

21. DUXBURY, supra note 18; STEVENS, supra note 15 , at 38.

22. See Aine Hyland \& Shane Kilcommins, Signature Pedagogies and Legal Education in Universities: Epistemological and Pedagogical Concerns with Langdellian Case Method, in 14 Teaching IN Higher Educ. 29, 29 (2009); Barbara Glesner Fines, Questions, Answers, and Law School Teaching 1 (unpublished manuscript), available at http://law2.umkc.edu/faculty/profiles/ glesnerfines/Q\&A.pdf [http://perma.cc/K5WH-PMND].

23. See Ruta K. Stropus, Mend It, Bend It, and Extend It: The Fate of Traditional Law School Methodology in the 21st Century, 27 LOY. U. CHI. L.J. 449, 453-54 (1996).

24. Id. at 454.

25. Some reject the Socratic approach to law teaching as entirely ineffective. See, e.g., John O. Sonsteng et al., A Legal Education Renaissance: A Practical Approach for the Twenty-First Century, 34 WM. Mitchell L. Rev. 303, 336-37 (2007).

26. The chicken-and-egg question remains: have sub-parts of the profession developed to value these skills as a result of generations of lawyers possessing those skills? Cf. Fines, supra note 22 , at 1 (explaining that "[m]ost attorneys are comfortable using questions as a teaching method because this. . . is a skill attorneys use on a regular basis"). 
responses to questions that require recall or inductive reasoning. If a desirable learning outcome is "reflect, research, and write a reasoned response," the Socratic method would not be a first choice for teaching toward, and assessing success in meeting, that learning outcome. A similar observation holds for a broad range of core legal work-interviewing clients, working in teams with other lawyers, negotiating deals, and even engaging in the vast majority of litigation work that is not arguing before a court, agency, or other neutral decision-maker.

2. General Incompatibility with Online Courses. - The case method and Socratic dialogue is less than perfectly amenable to teaching using online methods. One-on-one verbal discourse between the professor and student, observed by other students who imagine themselves in the hot-seat, is difficult to conduct at a distance. Synchronous teaching using audio-conference or chat-room technology makes Socratic dialog possible, but stilted.

By removing the time constraints on student responses, asynchronous online teaching undermines the Socratic dialogue exercise entirely. Students in asynchronous online courses sign onto the course website on their own schedule. It is possible in an asynchronous course for the professor and student never to interact in real time. ${ }^{27}$ Because there is no expectation of real-time discourse, posing a difficult question does not require under-pressure reasoning. It instead permits students to log off, ponder their response, and return to the course website having satisfied themselves that they are prepared to respond. Students may even have consulted with classmates or outside sources before responding.

The difficulties faced in reproducing century-and-a-half old teaching methods in online instruction likely explains institutional reluctance to move quickly into online teaching. Law professors seeking to emulate their own educational experiences may reject innovations that undermine in-person Socratic dialogue. Law faculty frequently come from the ranks of judicial clerks and appellate lawyers, where they have found their particular skill sets highly prized. ${ }^{28}$

That experience may justify in their mind a disinclination to innovate. Where those faculty are open to online teaching, synchronous courses, which can be conducted exactly like live courses, tend to be preferred to asynchronous courses. Early forays into online law teaching are represented by primarily synchronous instruction. ${ }^{29}$ Synchronous teaching is the easy choice because it does not require

27. Consider the example of my own Comparative and International Competition Law course from spring 2015. See infra Part III.

28. See Susan P. Liemer \& Hollee S. Temple, Did Your Legal Writing Professor Go to Harvard?: The Credentials of Legal Writing Faulty at Hiring Time, 46 U. LouisviLle L. Rev. 383, 393-94 (2008).

29. For example, one third party involved in facilitating online teaching arranges to have most classes taught in synchronous format, advertising that " $[\mathrm{t}]$ he synchronous format, along with message boards, chat rooms, online faculty office hours and email allows faculty-student interactivity comparable to a traditional classroom." Summer 2016, ILAw, http://www. ilawventures.com/online-summer-courses [http://perma.cc/7SHD-THSM] (last visited Sept. 25, 2015). Concord Law School in California, an early mover in non-ABA-accredited fully-online J.D. 
faculty to change from the casebook, lecture, and Socratic dialog methodology that has prevailed throughout their careers.

In contrast, if one prioritizes outcomes other than real-time verbal responses to questions requiring factual recounting and exercise of analytical skills, the teaching methods available in online course design promise superior results. Fortunately for education innovators seeking to increase the use of online teaching in law schools, changes in the dominant teaching methodology have been underway for many years and over the past decade have become accepted as the new norm. ${ }^{30}$ Beginning with the 2014 amendments to the American Bar Association's Standards for Accreditation of Law Schools, many of those methodological changes are becoming institutionalized. ${ }^{31}$

\section{B. Practice Readiness: Skills and Experiential Learning}

1. Carnegie Report.-Since at least 1914, the Carnegie Foundation has studied law teaching and published reports suggesting innovations. ${ }^{32}$ In 2007, the Carnegie Foundation for the Advancement of Teaching published a report ("the Carnegie Report") on law school education, recognizing the strengths of legal education in developing analytical thinking, but criticizing its disconnect from the legal profession itself. ${ }^{33}$

The Carnegie Report identified qualities and flaws in legal education, as it had developed by the early 2000s. ${ }^{34}$ Law teaching through the case method using the leading Socratic dialogue approach teaches critical thinking, but is believed to offer little success in practical skills and professional responsibility. ${ }^{35}$

The Carnegie Report made two summary conclusions: (1) law schools should better prepare students for the profession of law by better integrating skills into the curriculum; (2) law schools should engage in the exercise of assessing their

degrees, chose to offer its courses synchronously. See Programs Overview, ConcoRd L. ScH., http://www.concordlawschool.edu/find-law-degree-programs.aspx [http://perma.cc/Y9BB-CLE9] (last visited Sept. 29, 2015).

30. See, e.g., Susan Sturm \& Lani Guinier, The Law School Matrix: Reforming Legal Education in a Culture of Competition and Conformity, 60 VAND. L. REV. 515, 515-19 (2007) (discussing changes to legal education overall, including pedagogy).

31. See generally Task Force on the Future of Legal Educ., Am. Bar Ass'n, Report AND RECOMMENDATIONS (2014), http://www.americanbar.org/content/dam/aba/administrative/ professional_responsibility/report_and_recommendations_of_aba_task_force.authcheckdam.pdf [http://perma.cc/7MJP-347F]. This task force report was the basis for the 2014 changes to the Standards for Approval of Law Schools.

32. William M. Sullivan et al., Educating Lawyers: Preparation for the PROFESSION OF LAW 18 (1st ed. 2007).

33. See id. at 1-20.

34. Id.

35. Id. at $187-188$. Whether the critical thinking skill can fairly be distinguished from "practical skills" remains a matter of considerable debate in the legal academy. 
degree programs. ${ }^{36}$ An early reaction was to require an increase in skills instruction with the introduction of a requirement of "substantial instruction in professional skills" for all accredited law schools. ${ }^{37}$ Seven years after its publication, both of the Carnegie Report's primary recommendations found their way into the ABA's revised Standards. ${ }^{38}$

2. Revised ABA Standards.-In 2014, the ABA revised its Standards and Rules of Procedure for Approval of Law Schools ("Standards"), which govern both newly-created schools seeking initial accreditation and established institutions whose educational programs are reviewed on a seven-year basis and are subject to some degree of oversight in the interim. ${ }^{39}$ The 2014 revisions to the Standards respond to changes in expectations of students, employers, and the public following an apparent decrease in the demand for law graduates following the 2008 recession. ${ }^{40}$ Students asked to graduate law school with less debt and a greater claim to "practice readiness" when the students reach the job market. ${ }^{41}$ The perception was that legal employers, who historically had considered it their role to train new lawyers in practical skills relevant to the particular job during the early years of a lawyer's career, were less interested in filling that role. ${ }^{42}$

The practice readiness goals are seen in Standard 301, requiring that law school graduates are prepared "for admission to the bar and for effective, ethical, and responsible participation as members of the legal profession." ${ }^{43}$ Recognizing that students rarely enroll in law school without intending to take and pass a bar exam, and legal practice is not available to students who do not pass this exam, ${ }^{44}$ the Standards require law schools to prepare students to achieve that goal. ${ }^{45}$ The

36. See id. at 185-202.

37. See Am. Bar Ass'n, Standards and Rules of Procedure for Approval of Law SCHOOLS 2013-2014 21-22 (2013), available at http://www.americanbar.org/content/dam/aba/ publications/misc/legal_education/Standards/2013_2014_final_aba_standards_and_rules_of_pr ocedure_for_approval_of_law_schools_body.authcheckdam.pdf [http://perma.cc/3H2Q-84PX]

38. See TASK Force on the Future of Legal Educ., supra note 31.

39. Section of Legal Educ. \& Admissions to the Bar, Am. Bar Ass'n, The Law SCHOOL ACCREDITATION PROCESS 5-9 (2013), available at http://www.americanbar.org/content/ dam/aba/publications/misc/legal_education/2013_revised_accreditation_brochure_web.authche ckdam.pdf [http://perma.cc/ZC89-J46L].

40. See TASk Force on the Future OF Legal Educ., supra note 31.

41. Id.

42. See, e.g., David Segal, What They Don't Teach Law Students: Lawyering, N.Y. Times, Nov. 20, 2011, at A1, available at http://www.nytimes.com/2011/11/20/business/after-law-schoolassociates-learn-to-be-lawyers.html?_r=0 [http://perma.cc/Z8RQ-QD9W].

43. AM. BAR. Ass' N, supra note 6, at 15. In reality, practice readiness and decreased law firm training are two sides of the same coin. Practice readiness simply means employers need to spend fewer resources training new lawyers before leveraging their work for profit.

44. However, exceptions exist. See Christina Spiewak, UW, Marquette law graduates not required to take bar exam, BADGER HERALD, Oct. 4, 2010, available at https://badgerherald.com/ news/2010/10/04/uw-marquette-law-gra/ [http://perma.cc/KDT9-B6FP].

45. Am. BAR. Ass'N, supra note 6 , at 15. 
Standards also require schools to establish learning objectives that include, at a minimum, competency in "[o]ther professional skills needed for competent and ethical participation as a member of the legal profession." 46

Finally, the revised Standards include more specific details regarding steps law schools must take to serve these and other objectives. Beginning in fall 2016, law schools are required to offer "one or more experiential course(s) totaling at least six credit hours." ${ }^{, 47}$ All accredited law schools, or startups seeking initial accreditation, are required to make experiential learning a significant part of their educational programs. ${ }^{48}$

The Standards also impose a new requirement of assessing student learning. Standard 314 commands: "A law school shall utilize both formative and summative assessment methods in its curriculum to measure and improve student learning and provide meaningful feedback to students." ${ }^{29}$ Interpretations of Standard 314 define the terms. Formative assessments are measurements of outcomes taken at an intermediate stage in the particular course or program, while summative assessments are measurements of outcomes taken at the end of the course or program. ${ }^{50}$ Standard 315 adds the requirement of "ongoing evaluation of the law school's program of legal education, learning outcomes, and assessment methods." ${ }^{51}$ Little guidance from the ABA exists currently on best practices for implementing Standards 314 and 315. As it turns out, best practices for course and program design in online teaching involve substantial reliance on diverse and regular assessment practices as well as tracking student learning outcomes, feeding directly into the ABA's new assessment requirements. ${ }^{52}$

I discuss the new Standards' changed treatment of online learning in law schools in the next Part. As law schools consider how to meet the requirements discussed in Standards 301, 302, and 303, online teaching offers promising opportunities. That is particularly the case where some of the clear routes to experiential and practice-ready teaching strategies, including adjunct-led programs with local firms, corporations, and government offices, are difficult to offer because of a school's semi-rural or small-town location.

\section{Promises OF ONLINE LEARNING FOR LAW SCHOOLS}

A number of factors have given rise to a desire for innovation in program design and teaching methods. These appear to include concerns for cost, practicereadiness, accessibility, and product differentiation (new and innovative degrees and programs). Online learning on a large scale is a recent innovation that may address many of these concerns. This Part discusses the promises of online

46. Id.

47. Id. at 16 .

48. See id. at 16-19.

49. AM. BAR. Ass'N, supra note 6, at 23.

50. See id.

51. See id. at 24.

52. See infra Part III. 
learning for improving law school teaching.

Online courses in law school offer several benefits, some obvious, some less so, and some even counter-intuitive. Benefits include reduced cost, improved access, and practice readiness. ${ }^{53}$ Reduced cost: presenting a quality online course is no less expensive than if the course is live, so tuition rates are not likely to be reduced. ${ }^{54}$ However, ancillary expenses of law school, including commuting or housing, may be reduced or eliminated.$^{55}$ Online classes may more easily leverage freely available online sources, reducing the casebook and supplement expenses that may approach ten percent of a student's overall direct expenses. ${ }^{56}$

Access may be improved: students in remote locales need not move to be geographically proximate to the school and students with a need to spend a semester away, perhaps pursuing an externship, can remain enrolled in online classes. ${ }^{57}$ Because facility with a variety of Internet-based communication methods is essential in a modern law practice, online teaching promotes practiceready graduates. All of these benefits exist, though they may be muted, in classes that are partly online.

Other benefits, less obvious on cursory analysis, also apply. Online teaching may help to address the needs in legal education that the Carnegie Report identified and the revised Standards have now institutionalized.

\section{A. ABA Limits and Work-Arounds}

Law schools' primary accrediting agency, the American Bar Association, imposes a comprehensive set of standards governing all aspects of juris doctor degree programs. ${ }^{58}$ Distance education has long been covered by the Standards. ${ }^{59}$ The Standards impose limits on when distance education may be offered in the

53. See, e.g., Jordan Friedman, Online Learning Holds Promise, Challenges for Low-Income Students, U.S. NEws \& WorLd REP. (Dec. 24, 2014, 9:30 AM), http://www.usnews.com/education/ online-education/articles/2014/12/24/online-learning-holds-promise-challenges-for-low-incomestudents [http://perma.cc/9JA8-C6YE] (discussing the advantages, including cost and access, and disadvantages of online college courses).

54. By "quality online course," I am excluding the Massive Open Online Course, or MOOC, that has been tried and failed both in and out of law schools. $C f$. Andrew Miller, 4 Lessons We Can Learn from the 'Failure' of MOOCs, EDUTOPIA (Jan. 30, 2014), http://www.edutopia.org/blog/4lessons-from-failure-of-moocs-andrew-miller [http://perma.cc/RMH8-2GXG] (analyzing the failings of early MOOCs and proposing standards for quality online courses). Law schools making substantial efforts at teaching online set tuition rates at levels that equal or approximate their full tuition rates. See e.g., The Hybrid Program, WM. Mitchell C. LAW., http://web.wmitchell.edu/ admissions/hybrid-program/, [http://perma.cc/857U-SW6P] (last visited Aug. 27, 2015).

55. See Friedman, supra note 53.

56. 10 Advantages to Taking Online Classes, Open Educ. Database (Jan. 10, 2012), http://oedb.org/ilibrarian/10-advantages-to-taking-online-classes/ [http://perma.cc/H4Y5-MXU4].

57. See Friedman, supra note 53.

58. See AM. BAR Ass'N, supra note 6, at 1-47.

59. Id. at 19. 
program, how much distance education students are permitted to pursue in terms of total credit hours, and how that education must be conducted to qualify as part of the educational program. ${ }^{60}$

1. The 2014-15 Standards.-Of the Standards' seven chapters, Chapter 3 is the source for how law schools must structure their J.D. programs ${ }^{61}{ }^{6}$ Standard 306 allows for distance education, including online teaching. ${ }^{62}$ Standard 306 was substantially amended in 2014 to increase the total number of credits permitted to be taught online and to increase the number of credits per semester that students may pursue online. ${ }^{63}$ Further amendments included eliminating a series of interpretations that clarified what teaching methods met the minimum requirements for distance education. ${ }^{64}$

As amended, Standard 306 reads:

(a) A distance education course is one in which students are separated from the faculty member or each other for more than one-third of the instruction and the instruction involves the use of technology to support regular and substantive interaction among students and between the students and the faculty member, either synchronously or asynchronously.

(b) Credit for a distance education course shall be awarded only if the academic content, the method of course delivery, and the method of evaluating student performance are approved as part of the school's regular curriculum approval process.

(c) A law school shall have the technological capacity, staff, information resources, and facilities necessary to assure the educational quality of distance education.

(d) A law school may award credit for distance education and may count that credit toward the 64 credit hours of regularly scheduled classroom sessions or direct faculty instruction required by Standard 310(b) if:

(1) there is opportunity for regular and substantive interaction between faculty member and student and among students;

(2) there is regular monitoring of student effort by the faculty member and opportunity for communication about that effort; and

(3) the learning outcomes for the course are consistent with Standard 302.

(e) A law school shall not grant a student more than a total of 15 credit hours toward the J.D. degree for courses qualifying under this Standard.

60. $I d$.

61. See id. at $15-25$.

62. Id. at 19-20.

63. Section of Legal Educ. \& Admissions to the Bar, Am. Bar Ass'n, Explanation OF CHANGES 9 (2014), available at http://www.americanbar.org/content/dam/aba/administrative/ egal_education_and_admissions_to_the_bar/council_reports_and_resolutions/201408_explanati on_changes.authcheckdam.pdf [http://perma.cc/675U-EGPG].

64. Id. 
(f) A law school shall not enroll a student in courses qualifying for credit under this Standard until that student has completed instruction equivalent to 28 credit hours toward the J.D. degree.

(g) A law school shall establish an effective process for verifying the identity of students taking distance education courses and that also protects student privacy. If any additional student charges are associated with verification of student identity, students must be notified at the time of registration or enrollment. ${ }^{65}$

The credit totals for allowed online courses reflect a twenty-five percent increase from the pre-2014 limit of twelve total credits online. ${ }^{66}$ The more substantial change is the permission for students to enroll in those credits in one semester, rather than being limited to four credits of online courses per semester. ${ }^{67}$ Students may now relocate across the country to enter the employment market while finishing their final semester of law school. ${ }^{68}$ Students with externships in Washington, D.C. or Brussels may pursue those opportunities while not getting behind on their credits. Law schools that do not increase online offerings to give students these opportunities are putting their students at a competitive disadvantage in the employment market.

The 2014 Standards retain the definition of a distance course as being one with more than one-third of the instruction presented online. ${ }^{69}$ The definition

65. AM. BAR Ass'N, supra note 6, at 19-20. The Standard is accompanied by two interpretations dealing with the technology used for distance education and the need for examination security:

Interpretation 306-1

Technology used to support a distance education course may include, for example:

(a) The Internet;

(b) One-way and two-way transmissions through open broadcast, closed circuit, cable, microwave, broadband lines, fiber optics, satellite, or wireless communications devices;

(c) Audio and video conferencing; or

(d) Video cassettes, DVDs, and CD-ROMs, if the cassettes, DVDs, or CD-ROMs are used in a course in conjunction with any of the technologies listed in paragraphs (a) through (c).

\section{Interpretation 306-2}

Methods to verify student identity as required in Standard 306(g) include, but are not limited to (i) a secure login and pass code, (ii) proctored examinations, and (iii) other technologies and practices that are effective in verifying student identity. As part of the verification process, a law school shall verify that the student who registers for a class is the same student that participates and takes any examinations for the class.

Id. at 20 .

66. Id. at 19 .

67. Id.

68. Id.

69. Id. 
leaves law schools significant flexibility to use online teaching techniques to supplement live classes or to replace portions of classes that are primarily taught live.

The revised Standards retained one substantial limit on fully realizing the benefits of online teaching. That limit is the impermissibility of online teaching before students have completed the initial twenty-eight credits in their J.D. program..$^{70}$ In the absence of such a limit, schools might see substantial benefits to online courses in, or before, the first year curriculum. For example, a summer "Legal Methods" course prior to enrollment in the first year might be provided online. ${ }^{71}$ That particular innovation would be a particular benefit to out-of-state students unable to relocate in time for a live Legal Methods course. Other courses like "Legal Research," which are readily presented online and make sense to offer during the first year of the J.D. program, face a similar hurdle. ${ }^{72}$

A final limit on online teaching in the J.D. program is the general requirement governing contact hours in J.D. courses. Revised Standard 310 governs the aw arding of class credits. ${ }^{73}$ To aw ard a credit hour, a course must offer instruction equal to fifty minutes of instruction weekly for fifteen weeks, equal to 750 minutes of instruction. ${ }^{74}$ Synchronous online courses, which meet at regularly scheduled times for set class periods, can calculate their minutes of instruction similarly to live classes. Asynchronous online courses are not amenable to a similarly simple calculation. As I describe below, the techniques for asynchronous teaching involve less pure content dissemination and more attention to course design.$^{75}$ Equating class time with particular design elements is a process that belies the bespoke nature of the design process. ${ }^{76}$

2. Variances and Expectation of Future J.D. Program Change.-The ABA grants waivers of its limits on pilot bases to test innovations. Called "variances," these may be granted on applications presenting justifications supporting the request. ${ }^{77}$ Standard 107 spells out the bases for variance applications, including "extreme hardship for the law school and/or its students"

70. Id.

71. It may be possible to end-run the limit in Standard 306(f) by making such a course a requirement for enrollment but not available for credit. Law schools that charge tuition by the credit hour rather than by the semester would find it difficult to offer such a course for no charge. An alternative solution is to offer Legal Methods as a hybrid course with less than $1 / 3$ of the class hours replaced by online teaching. At McKinney we have followed this second approach.

72. At the McKinney School of Law, Legal Research is taught online, but has been moved to the summer following students' first year of school to comply with the twenty-eight credit rule. See Required Basic-Level Courses, InD. U. RoberT. H. McKinnEy SCH. LAw, http://mckinneylaw. iu.edu/courses/required-jd.cfm [http://perma.cc/MYX4-JZ6U] (last visited Sept. 29, 2015).

73. AM. BAR Ass'N, supra note 6, at 21.

74. Id.

75. See infra Part III.

76. See infra Part III.

77. AM. BAR Ass'N, supra note 6, at 7.

78. Id. Presumably, the better argument is hardship for students. 
actions that ... are experimental or innovative and have the potential to improve or advance the state of legal education." 79

One law school in Minnesota recently achieved ABA approval of a variance from the limits on online courses, permitting that school to present a J.D. program that was approximately $50 \%$ online and $50 \%$ classroom. ${ }^{80}$ The ABA determined that the school's program was "well- designed" and that "the benefits of the experimental program outweigh[ed] its risks." ${ }^{\text {81 }}$ Dubbed "[t]he Hybrid Program," that school's J.D. degree consists of part online and part live classes, and advertises itself as relying on pre-recorded lectures, live chats, moderated discussion forums, and video analysis of professional skills practice. ${ }^{82}$

Reasons exist to expect that the Minnesota experiment is an opening for greater permissiveness of law school online programs. Online learning has not been subject to retrenchment in any sector of education. Students now appear to expect to be able to take online courses to complement their live programs. A large and increasing percentage of U.S. law schools have some courses online ${ }^{83}$ and it is likely that in every law school, online teaching techniques are used to complement live classes, producing "hybrid" classes. ${ }^{84}$

Discussions about further change to the Standards revolve around means to make law school more affordable and to increase student flexibility to pursue outside employment or to get started on their careers. ${ }^{85}$ At the same time, there is reluctance to reduce the required coursework by eliminating the third year of law school. ${ }^{86}$ No innovation in the history of U.S. legal education in recent memory promises the flexibility and savings benefits more so than does online teaching.

79. Id.

80. See Council Grants Variance to William Mitchell College of Law, Am. B. Ass'N. http://www.americanbar.org/content/dam/aba/administrative/legal_education_and_admissions_t o_the_bar/council_reports_and_resolutions/2013_william_mitchell_hybrid_variance_announce ment.authcheckdam.pdf [http://perma.cc/YV8S-2ZQX] (last visited Sept. 29, 2015). William Mitchell College of Law's variance was granted in December 2013 under Standard 802 of the immediate past version of the Standards. Id.

81. Id.

82. See The Hybrid Program, supra note 54.

83. See, e.g., JD Law Course Online, J.MARSHALL L. SCH., http://www.jmls.edu/academics/ d/ d-online.php [http://perma.cc/QJ8N-JXK4] (last visited Sept. 5, 2015).

84. See, e.g., Class \& Exam Schedules, Ind. U. Robert H. McKinney Sch. Law, http://mckinneylaw.iu.edu/students/schedules.cfm [http://perma.cc/LQ5W-YEBA] (last visited Sept. 5, 2015).

85. See, e.g., TAsk Force on the Future of Legal Educ., Am. Bar. Ass'n, Draft Report AND RECOMMENDATIONS (Sept. 20 2013), available at http://www.americanbar.org/content/ am/aba/images/news/PDF/draft_report_of_aba_task_force_september_2013.pdf [http://perma.cc/CB2E-K4VA].

86. See, e.g., Colleen Flaherty, 2 Years for Law School?, InSide HighER Ed (Aug. 23, 2013), https://www.insidehighered.com/news/2013/08/26/president-obama-calls-cutting-year-law-school [https://perma.cc/GNJ8-KXB4]. 


\section{B. Non-J.D. Programs}

The ABA limits on online courses do not apply to other degree or certificate programs, including graduate certificates, L.L.M.s, and the new Master of Jurisprudence ("M.J.") degree. ${ }^{87}$ Graduate certificates and degree programs not subject to ABA limits create opportunities for students without the opportunity cost of the traditional law school program. They should also be attractive to employers, whether traditional legal employers or firms with needs for expertised non-lawyers, as a means for employee training beyond that which can be provided in-house.

My institution has a graduate certificate in Corporate and Commercial Law ${ }^{88}$ that will, in the near term, be available entirely online and may be marketed to non-J.D. students or to practicing lawyers seeking to shift their area of focus in practice. Students can pursue the certificate to achieve concentrated knowledge and experience in business law topics. ${ }^{89} \mathrm{We}$ also anticipate being able to make an M.J. degree available entirely online. Target audiences for both programs-a freestanding Corporate and Commercial Law graduate certificate and the M.J. program for non-lawyers-are regional students with education needs that cannot be met in their hometowns, but for whom the opportunity costs of commuting to a different city for scheduled classes are substantial. Working professionals, active-duty military service-persons, homemakers, and mobility-challenged students will have access to law school education and will bring to the online classroom diverse experiences and backgrounds that are missing in live classroom settings.

In many cases, non-J.D. degrees or certificates arise as part of topic-specific centers or programs. When presented online, geographic markets for both teachers and students become global, increasing possibilities for well-run topicspecific programs. An increasing number of U.S. law schools have subjectspecific M.J. and L.L.M. programs available entirely online. ${ }^{90}$

\section{MCKINNEY LAW ONLINE: THE ONLINE EXPERIENCE AT THE MCKINNEY SCHOOL OF LAW}

This Part serves as a case study, highlighting the experience of online teaching at my own institution-the Indiana University Robert H. McKinney School of Law. The Part first describes the program of online education as it

87. A Master of Jurisprudence degree is a master's degree for non-lawyers, typically requiring between twenty-four and thirty credit hours of coursework. See M.J. Program, IND. U. RoBERT H. MCKINNEY SCH. OF L., http://mckinneylaw.iu.edu/admissions/mj/index.html [http:// perma.cc/NJZ8-95V8] (last visited Sept. 5, 2015).

88. See Graduate Certificate Requirements, Ind. U. Robert H. McKinney Sch. Law, http://mckinneylaw.iu.edu/courses/certificates.cfm [http://perma.cc/ZNH5-V6DY] (last visited Sept. 5, 2015).

89. Id.

90. Sonsteng et al., supra note 25 . 
exists and as it is developing. The Part then highlights three specific aspects: the course design process, the quality control process, and an experience with one particular online course.

\section{A. The Program}

The McKinney School of Law's parent institution, Indiana University ("IU"), made a substantial commitment to online courses, programs, and degrees under the leadership of President Michael McRobbie. ${ }^{91}$ Announced in fall 2012, the initiative included the commitment of $\$ 8$ million in seed money with the goal that every professional school in the Indiana University system would develop at least one online program. ${ }^{92}$ The Robert H. McKinney School of Law took steps to implement President McRobbie's charge. ${ }^{93}$

Under the leadership of Dean Andrew Klein, the McKinney School of Law established the "McKinney Law Online" initiative. ${ }^{94}$ Dean Klein appointed a Faculty Director of Online Programs and made available resources, including staffing and technology resources and summer grant funds, for online program development. ${ }^{95}$ McKinney Law Online took steps to encourage broad faculty participation in online course creation. ${ }^{96}$

The McKinney Law Online program rests on four pillars. First, the school is committed to top-quality course design and presentation, using the best available technologies and pedagogical techniques and relying on extensive course design assistance. Second, the school has a target for a steady-state level of online courses and programs in the curriculum. Current goals are to offer between twenty and twenty-five courses on a regular rotation. Those courses may be arranged into concentrations, graduate certificates, or degrees. Third, the school has a goal of continued recruitment of faculty and staff into online course design and presentation. In the medium term, one out of every two faculty members at McKinney might be expected to teach an online course. Fourth, the school has the

91. Press Release, Indiana University, Indiana University Announces IU Online, a Major New Online Education Initiative (Sept. 5, 2012), available at http://newsinfo.iu.edu/news/ page/normal/23061.html [http://perma.cc/DEJ4-FWPT].

92. Id.

93. University Information Technology Services, IND. U., https://uits.iu.edu/[http:// perma.cc/S3P4-J3R4] (last visited Sept. 5, 2015); see also The Center for Teaching and Learning, IUPUI, http://ctl.iupui.edu/ [http://perma.cc/98C9-YMDE] (last visited Sept. 5, 2015).

94. See generally Online Learning Program at IU McKinney Strives for Excellence, IND. U. ROBERT H. MCKInNEY SCH.LAw (Aug. 14, 2015), http://mckinneylaw.iu.edu/news/releases/2015/ 08/online-learning-program-at-iu-mckinney-strives-for-excellence.html [http://perma.cc/VE6NL72R].

95. Id.; see also What are Rubrics, IUPUI, http://ctl.iupui.edu/OnlineTeaching/ImplementingYour-Design/Assessment-Activities/Rubrics/What-are-Rubrics [http://perma.cc/9KBZ-MA9Y] (last visited Sept. 5, 2015).

96. Max Huffman et al., Partnering to Create Effective Online Legal Education, YouTuBE (June 24, 2015), https://www.youtube.com/watch?v=jVYjNwubr18 [http://perma.cc/HB83-ZF6N]. 
goal of recruiting students into McKinney Law Online. In the near term, every McKinney School of Law student should be able to enjoy the convenience and learning benefits of at least one online course. Additionally, McKinney Law Online expects to attract a new cohort of students, for whom attending live classes is an insurmountable barrier to legal education, to the law school through its online program.

1. Case Study 1: Course Design Process.-Experiment and experience are showing it to be true that carefully designed online courses promise better learning outcomes than do live classes ${ }^{97}$ One consistently reported conclusion is that learning effectiveness, as measured by student grades, is unaffected by the mode of instruction. ${ }^{98}$ A substantial Department of Education study goes further, concluding that online learning "has been modestly more effective, on average, than the traditional face-to-face instruction with which it has been compared" in the study. ${ }^{99}$

Survey data suggests that with regard to one facet of the educational experience-student comfort in participation-online courses offer substantial benefits. ${ }^{100}$ Class participation is a baseline expectation for law school courses, in particular those that draw upper-level students and are as much concerned about the analytical process as they are about content dissemination. Anecdotal experience finds that phenomenon is highlighted in asynchronous classes. One student comment following completion of an early asynchronous offering from McKinney Law Online highlighted the increased interactivity with classmates that student experienced. ${ }^{101}$ As I discuss above, apparent concerns for the loss of participation underlie some of the reluctance to innovate out of the traditional live class format, or where innovation occurs, to do so tentatively by using a model of synchronous instruction. ${ }^{102}$ The lesson that participation instead increases in an asynchronous online course should strengthen law schools' willingness to innovate in this direction.

To achieve the outcome benefits that academic research suggests are available with online courses, we have followed four design principles in our

97. See, e.g., Anna Ya Ni, Comparing the Effectiveness of Classroom and Online Learning: Teaching Research Methods, 19 J. PuB. AFF. ED. 199 (2013) (recognizing that studies of teaching effectiveness that exist are conducted in non-law-school settings and extrapolation may be difficult); see also Miller, supra note 54.

98. Id.

99. Barbara Means et al., U.S. Dep't of Educ., Evaluation of Evidence-Based Practices in OnLine Learning: A Meta-Analysis and Review of OnLINE LEARNing STUdies 1, 71 (2009), available at http://www.nachi.org/documents/US-Department-of-Education-OnlineEducation-Report.pdf [http://perma.cc/Z3ST-SX2P] (emphasis in original).

100. Id. at 18 (reporting survey data and citing earlier studies reaching the same result).

101. IU McKinney Online!, YouTube (Aug. 28, 2015), https://www.youtube.com/watch? $\mathrm{v}=\mathrm{V} 4 \mathrm{y} 8 \mathrm{TS}$ youHw\&feature=youtu.be [http://perma.cc/D49L-U92Z] (including comments by McKinney student Jessica Hilger about her interactions with her classmates during her online course).

102. See supra Part I.A. 
course creation and program development. ${ }^{103}$ First, we partnered with course design experts made available through our parent institution. ${ }^{104}$ Second, we concentrated our efforts on asynchronous design because of the design and teaching flexibility that it creates. ${ }^{105}$ Third, we followed a process of bespoke course design with the goal of meeting previously established learning outcomes. ${ }^{106}$ Fourth, we insisted on careful peer review and quality control to ensure new online courses from McKinney Law Online meet the promise of equal or better outcomes than live courses with the same educational objectives. ${ }^{107}$

a. Partnership.-Partnership is a process of allying with outside experts and offices. Through the IU Online Initiative, resources have flowed to our campus' Center for Teaching and Learning (CTL) and to a new office, e-Learning Design Services (eDS), created under the umbrella of IU Online. ${ }^{108}$ These partnerships bring to the table resources-including software, hardware, recording studios, and even financial incentives - to supplement the resources available from the McKinney School of Law. Our alliances enable us to work with course designers, whose prior experience draws from schools across the university, including schools of education, health, nursing, business, music, and liberal arts. ${ }^{109}$

Such cross-university experience is particularly valuable for law schools that are frequently distant, both physically and politically, from the heart of the university. Most importantly, our partnerships bring to the table everything from design expertise and exposure to the latest in academic research regarding online pedagogy. ${ }^{110}$ These partnerships have informed the course development in nearly all of our newly created online classes.

b. Asynchronous design.-Asynchronous design is necessary to take advantage of the convenience benefits of online teaching, both for faculty and for students. "Convenience" is a question of reduced opportunity cost. Students studying asynchronously can choose what of their alternative uses of time are least valuable and shift their studies so they are replacing those non-valuable alternatives, perhaps bad television programming, instead of valuable alternatives,

103. See generally Huffman et al., supra note 96; Max Huffman et al., Time-Shifting in the Age of Dr. Who-Designing Interactive Asynchronous Skills and Seminar Course, YouTuBE (June 19, 2015), https://www.youtube.com/watch?v=BcWr-8Qqvwc [http://perma.cc/HTW6-8DJY] [hereinafter Time-Shifting].

104. See generally Time-Shifting, supra note 103.

105. See generally id.

106. See generally id.

107. See generally id.

108. See Indiana University Online, supra note 2; University Information Technology Services, supra note 93; The Center for Teaching and Learning, supra note 93; Huffman et al., supra note 96; Time-Shifting, supra note 103.

109. See Indiana University Online, supra note 2; University Information Technology Services, supra note 93; The Center for Teaching and Learning, supra note 93; Huffman et al., supra note 96; Time-Shifting, supra note 103.

110. See University Information Technology Services, supra note 93; The Center for Teaching and Learning, supra note 93; Huffman et al., supra note 96; Time-Shifting, supra note 103. 
perhaps a child's soccer practice. A program boasting asynchronous courses eliminates concerns with time zone conflicts, enabling courses to be offered around the globe. It mitigates, though does not entirely eliminate, other scheduling conflicts that may present entry barriers to students and faculty. ${ }^{111}$ Asynchronous design also gives access to a broad range of pedagogical innovations including discussion boards, formative assessments such as quizzes and midterms, student reflection exercises, and student team-work assignments. ${ }^{112}$

c. Bespoke design.-Bespoke design ensures that courses are built in the way that best serves the course-level educational objectives. The design process is backward in nature. First, faculty work with course designers to articulate desired outcomes- "what will students be able to do after successfully completing this course?" The next step in the process is identifying the assessment strategy that best evaluates the accomplishment of those outcomes. And finally, the creating faculty and course designer work to design a course structure that builds to the identified assessment strategy.

Course designers with whom McKinney faculty have collaborated often bring to the first meeting a "backward design template" that facilitates the design process. One version of the backward design template is reproduced below:

\begin{tabular}{|l|l|l|l|l|l|}
\hline Lesson/Unit X (Week Y) & $\begin{array}{l}\text { Map to } \\
\text { Course } \\
\text { Outcomes }\end{array}$ & $\begin{array}{l}\text { Instructor } \\
\text { Generated } \\
\text { Content }\end{array}$ & $\begin{array}{l}\text { Practice/ } \\
\text { Learning } \\
\text { Activities }\end{array}$ & Assessments/Evidence & $\begin{array}{l}\text { Delivery } \\
\text { Method }\end{array}$ \\
\hline & & & & & \\
\hline & & & & & \\
\hline & & & & & \\
\hline & & & & & \\
\hline
\end{tabular}

The discussion in this paragraph of bespoke design may appear at odds with the discussion in the prior paragraph of a preference for asynchronous course design. Certainly a bespoke design process must accommodate synchronous and even live meetings when the faculty and designers agree that those are the only or most effective means to achieve the course outcomes. As I note above, traditional Langdellian pedagogy produces outcomes ideally suited for some legal careers. ${ }^{113}$

111. Some scheduling challenges continue in courses that include assignments with due dates and require students to engage with course material during set periods during the semester. See Huffman et al., supra note 96; Time-Shifting, supra note 103.

112. None of those are unique to asynchronous online courses, but where students are required to prepare for and to attend regular lectures, there is limited capacity for innovative design elements. See Huffman et al., supra note 96; Time-Shifting, supra note 103.

113. See supra Part I. 
Those techniques should be employed where innovative techniques do not offer improvements in meeting outcomes. Where, however, the outcomes sought include lawyering skills that rely on reflection, writing, and strategizing, asynchronous course design can meet those outcomes more effectively than either live or online-synchronous instruction. The backward design process has taught us that serving the academy's increased emphasis on teaching a diversity of lawyering skills favors a move to online teaching.

Bespoke design offers another substantial benefit that programs seeking to ramp up quickly may fail to realize. Individual faculty personality, subject-matter expertise, and teaching style are respected in a course-by-course design process in a way that they are not in a more rigid top-down design process. Such respect for faculty autonomy is a core value of U.S. legal education. The countervailing limitation is one of scalability: individual course design is a cumbersome process requiring a substantial resource investment. It is perhaps not surprising that forprofit third party vendors seeking to offer online courses by contract anecdotally appear to favor scalability over diverse teaching methods. In contrast, when nonprofit law schools build online programs from the ground up, the values of autonomy and diversity render scalability a secondary goal.

d. Quality control.-Peer review and quality control are the final principles of the McKinney Law Online course design process. IU has contracted with a leading online course design quality control program, Quality Matters. ${ }^{114}$ Quality Matters offers training for faculty in course design principles tailored to an online setting. ${ }^{115}$ Most McKinney faculty currently teaching online or developing courses for online presentation have been trained in the Quality Matters rubric for online course design. Using that rubric as a guide, in partnership with CTL and eDS we implemented a pre-semester peer review process for all new courses presented as part of McKinney Law Online. The peer review caps a design and development process that is many times more careful and involved than the design process for nearly any other course in the law school curriculum.

The Quality Matters-inspired peer review offers two additional benefits. First, McKinney faculty and their course design partners are exposed to the multitude of design choices in the various courses under development. Designing faculty enjoyed a pedagogical ferment that is rare in an institution, like most U.S. law schools, with siloed expertise and teaching responsibilities. Second, McKinney Law Online is developing a collection of historic peer review documents that can inform future course design projects.

2. Case Study 2: Comparative and International Competition Law.-

a. Asynchronous online teaching is a disruptive innovation.-The theory of disruptive innovation describes products that create new markets rather than merely tweaking at the margins of existing ones. ${ }^{116}$ Disruptive innovation may

114. QuALiTY MATTERs, https://www.qualitymatters.org/[http://perma.cc/75K2-QAFP] (last visited Aug. 22, 2015).

115. Id.

116. Clayton Christensen, The Innovator's Dilemma: When New Technologies Cause Great Firms to Fail 20 (2013). 
occur because, counterintuitively, it is less expensive than incremental improvement, permitting the innovator to ignore the industry standard and to start from scratch. ${ }^{117}$

Elective business-law courses like antitrust compete against courses in other subjects like criminal procedure, bankruptcy, patent law, and civil rights. As a competitor in a market for student registrations, antitrust professors suffer a disadvantage ${ }^{118}$ Students matriculating into the J.D. program frequently espouse interests in criminal law, civil rights, constitutional law, and corporate law, as well as abstract ideas such as "social justice." Students rarely have a priori interests in antitrust or even in an abstract idea like "economic regulation." I also see a frustrating dearth of diverse students in my antitrust courses. In one recent semester, three of twenty-two students were women. ${ }^{119}$ The disadvantage is exacerbated in a specialty course like Comparative and International Competition Law ("CICL").

Faculty in fields like mine must innovate to compete. ${ }^{120}$ My single most successful innovation, as regards recruiting students and achieving positive student feedback, has been to move CICL out of the classroom and into an online setting.

Student demand for online classes is high, ${ }^{121}$ particularly in the third year or in part-time programs when externships, study abroad programs, and employment opportunities increase the opportunity cost of showing up for live classes. Taking my CICL class online last spring increased my subscribership from eight students the last time I taught the course (four years earlier, in 2011) to twenty-seven. Those twenty-seven students included a substantial population of female and minority students, as well as students based in diverse geographies, including the Netherlands (study abroad), North Carolina, Florida, Texas, and Arizona.

Teaching online makes use of freely available resources a natural process, including sending students to AB A lunchtime brown bag sessions on cutting-edge

117. Id.

118. Elie Mystal, Best Classes for BigLaw, ABove LAw, http://abovethelaw.com/2014/02/ best-classes-for-biglaw/ [http://perma.cc/YW5Y-7R9K] (last visited Aug. 22, 2015) (excluding antitrust classes from the list of recommended law classes).

119. This is a report based on anecdotal evidence from my own teaching. In contrast, in a recent survey year, data from the American Bar Association demonstrates that nearly $30.7 \%$ of male full-time J.D. program matriculants were of minority ethnic backgrounds. For women, the percentage was closer to $30 \%$. Women made up approximately $46.5 \%$ of all matriculants to fulltime J.D. programs. See Statistics, AM. B. Ass'N, http://www.americanbar.org/groups/legal_ education/resources/statistics.html [http://perma.cc/34XJ-44EU] (last visited Aug. 22, 2015). A casual look at the data suggested to me that my classes lacked a needed competitive edge.

120. The tenure contract offers limited protection. Course assignments depend on student demand and no faculty member lasts long teaching courses with no student demand.

121. Kelsey Sheehy, Online Course Enrollment Climbs for the 10th Straight Year, U.S. NEwS \& WORLD REP. (Jan. 8, 2013, 6:20 AM), http://www.usnews.com/education/online-education/ articles/2013/01/08/online-course-enrollment-climbs-for-10th-straight-year [http://perma.cc/XU489447]. 
and relevant topics, ${ }^{122}$ directing students to oral argument audio broadcasts, and assigning the latest Supreme Court slip opinions. Those opportunities are not unavailable to students in live classes, but the increased flexibility available to faculty and students with online classes makes capitalizing on them more natural.

Statutes are easily findable on subscription-based databases or for free with websites like Findlaw ${ }^{123}$ and the Cornell Legal Information Institute. ${ }^{124}$ In CICL, materials available through the international and overseas governmental entities, including the International Competition Network ${ }^{125}$ and various overseas jurisdictions' Internet sites ${ }^{126}$ give both a broad and a deep exposure to the variety of laws and cases applying those laws from around the globe.

Relying on a variety of sources instead of relying only on the self-contained casebook better approximates the real-world environment in which students as lawyers will discover, learn, and apply the law. This process is not unique to CICL. Many online courses capitalize on the myriad publicly available resources to maintain a diverse menu of sources of information and types of media with which students can engage. Teaching online can improve learning outcomes even while decreasing entry barriers to courses like CICL.

b. Asynchronous online teaching can beat the live classroom.-We designed CICL to be run entirely online and asynchronously. The course comprised a variety of assigned readings, recorded mini-lectures, instructor-created text expanding on particular topics, low-value comprehension quizzes, writing assignments, discussion boards, and student-to-student engagement through both discussion boards and peer reviews of classmates' work. The course included students at the McKinney School of Law as well as those from three other schools, using a third-party vendor to market the course more broadly. The level of student involvement and comprehension demonstrated by students' substantive written products far exceed what I experienced when I last taught the class as a live seminar.

The variety of learning methods employed in CICL reflects the different learning outcomes we sought to achieve. One outcome-producing for dissemination to potential employers a "major scholarly work"- necessitated making the course a writing class. Other outcomes made it important that classwork prepared students to counsel clients on differences between antitrust systems worldwide and to engage in written analysis of hot topics in antitrust law.

122. ABA lunchtime brown-bags are free for academics and students. See, e.g., Brown Bag Sessions, AM. B. Ass'N, http://www.americanbar.org/groups/gpsolo/events_cle/brown_bag_ sessions.html [http://perma.cc/KH2Y-6UR6] (last visited Aug. 22, 2015).

123. FINDLAw, http://www.findlaw.com/ [http://perma.cc/L6R7-AGBE] (last visited Aug. 22, 2015).

124. CoRnell U. Legal INFO. InSt., https://www.law.cornell.edu/ [http://perma.cc/9G6QC645] (last visited Aug. 22, 2015).

125. InT'L COMPETITION NETWORK, http://www.internationalcompetitionnetwork.org/ [http://perma.cc/MHF8-Z9H4] (last visited Aug. 24, 2015).

126. See, e.g., Competition, EuroPEANCOMMISSION, http://ec.europa.eu/competition/index_ en.html [http://perma.cc/UR6P-28UQ] (last visited Aug. 21, 2015). 
All of these diverse legal skills were best learned asynchronously with time to reflect, research, edit, and draft carefully.

More generally, experience with online course design and presentation shows two areas in which the asynchronous online course consistently produce results that are superior to what can be achieved in the live classroom setting. First is an interactivity strategy - the use of discussion boards to achieve substantive engagement among students and between the professor and the students. Second is an assessment strategy - the use of formative assessments to ensure student comprehension and adjust teaching during the semester. ${ }^{127}$

\section{B. Interactivity Strategy: Online Discussion Boards}

Careful online course design creates expectations of and ample opportunity for interactivity among students, between students and professors, and between students and course material. ${ }^{128}$ The usual means of achieving interactivity in a live or a synchronous class is class discussion. If explanation and analysis conducted in a discussion setting is one of the class learning outcomes, some means of conducting and grading class discussion should be part of the course design.

Online discussion boards may be the most frequently cited replacement for synchronous class meetings. ${ }^{129}$ Appropriately designed, asynchronous online discussion boards are highly effective. Benefits of asynchronous discussions include the following: (1) as with all asynchronous teaching techniques, they are more convenient for busy students; (2) student comments may be more fully considered and therefore more thoughtful; (2) the frequently-complained-of perception of anonymity in Internet communication ${ }^{130}$ has the beneficial effect of encouraging reticent students to participate; (3) the discussion board creates a permanent record that enables students to refer back to the board as a review tool;

127. Both of these are explicitly referenced in the ABA Standards. See AM. BAR Ass'N, supra note 6 , at 19 (requiring interactivity in distance education courses); id. at 23 (requiring both formative and summative assessment methods).

128. The ABA Standards require "regular and substantive interaction among students and between the students and the faculty member." Id. at 19 (discussing Standard 306(a)). Further guidance is not provided in the 2014-15 Standards. The immediate past version of Standard 306 included an interpretation that explained that students should have "opportunities to interact with instructors that equal or exceed the opportunities for such interaction with instructors in a traditional classroom setting." AM. BAR Ass'N, supra note 37, at 28 (discussing Standard 306 and Interpretation 306-4).

129. Discussion boards have been in use in Internet communication for decades. One source dates the earliest examples to the late 1970s, with more common use as fora for topical discussions evolving in the early 1990s. See Internet Forum, WIKIPEDIA, https://en.wikipedia.org/wiki/ Internet_forum [https://perma.cc/RZ5L-G7NR] (last visited Aug. 24, 2015).

130. See, e.g., David Davenport, Anonymity on the Internet: Why the Price May Be Too High, 45 Сомм. ACM 33 (2002), available at http://www.csl.mtu.edu/cs6461/www/Reading/ Davenport02.pdf [http://perma.cc/T859-S9BX]. 
(4) the discussion board creates a record that facilitates both grading and post-hoc analysis of the effectiveness of class lessons. ${ }^{131}$

What is meant by "class discussion"? Here is an excerpt from the "Instructions for Discussion Boards" page on the CICL course site:

Imagine you know one thing: "Microsoft Corporation was a monopoly and it got into antitrust trouble." Your classmate knows something else: "Microsoft engaged in exclusionary conduct with regard to Netscape Navigator, a now defunct web browser." And another classmate knows something else: "Microsoft viewed web browsers as threats to its operating system monopoly." Among the three of you, you know the true (if yet incomplete) story that Microsoft Corp., which had a monopoly in operating systems, was taking action to preserve that monopoly by limiting competition from Netscape Navigator through a course of exclusionary conduct. That is no small accomplishment.

For that reason a class discussion is conducted among all of us. It is not a series of bilateral conversations each of you has with me while others observe. The discussion differs from a Socratic dialog that you experience in class, where I ask a question, you respond, and I follow up with more questions. You should see your role as interacting with the entire conversation, not just with the starting questions.

Learning objectives for discussion boards: [a] student with robust participation in a discussion board should:

1. [a]rticulate sophisticated analyses and explanations of matters pertinent to the topic of the board;

2. [c]ontribute to the crowd-sourced analytical process by reacting to other posts and by following up on reactions to that student's posts;

3. [g] ain a richer understanding of the topic, including resolving preexisting questions;

4. [p]ractice text-based interaction with professional colleagues on substantive legal issues. ${ }^{132}$

Similar outcomes might be achieved under the leadership of a skilled instructor in a live class. For two reasons, however, the online discussion proves to be a superior approach to achieving interactive learning. First, students too frequently self-select into or out of class discussions based on their own comfort levels. ${ }^{133}$ That self-selection is particularly troubling if one believes that the

131. Other benefits have been cited. See, e.g., Mastering Online Discussion Board Facilitation, EDUTOPIA, http://www.edutopia.org/pdfs/stw/edutopia-onlinelearning-masteringonline-discussion-board-facilitation.pdf [http://perma.cc/DP5E-YHD7] (last visited Sept. 5, 2015).

132. The CICL course syllabus is available upon request from the author.

133. Lorraine F. Normore \& Brandy N. Blaylock, Effects of Communication Medium on Class Participation: Comparing Face-to-Face and Discussion Board Communication Rates, 52 J.EDUC. 
students who select out are either students from underrepresented backgrounds (who select out based on being uncomfortable) or students who are most in need of instructor guidance (who selected out based on feelings of confusion or inferiority). Skilled instructors may be able to coax reluctant students into participation, but students" "hiding" in the live class setting may be as old as Socratic dialogue. ${ }^{134}$

Second, objectively grading the discussion in a live class can be a challenge. One problematic approach is for instructors to develop subjective senses over the course of the semester of which students were unique contributors and which were less active. Instructors frequently resort to making checkmarks on a class roster next to the names of students with particularly valuable contributions. Students who are unprepared may receive "X"s next to their names. A more nuanced approach might be for the instructor to assign a zero (unprepared), one (small contribution), two (unique insight), or three (comment carries the discussion). The rapid-fire nature of live class discussion makes anything more nuanced than that prohibitively difficult. Too sophisticated grading rubrics applied in the live classroom setting are subject to subjectivity based on random factors, such as instructor mood, and less random (and pernicious) factors, such as implicit bias. If a student or group of students raise complaints about subjective grading, no evidence remains of the live class discussions to support the grading decisions. ${ }^{135}$

Online discussion boards mitigate these concerns. Perceived anonymity and opportunity to reflect before contributing encourages student participation. An instructor can create a rubric that provides some objectivity to the grading and helps to set student expectations. ${ }^{136}$ And the online board creates durable evidence $^{137}$ of student contributions. Durable evidence facilitates instructor objectivity by moving the grading process out of what Nobel Laureate Daniel Kahneman has labeled the System 1 cognitive process, subject to implicit bias, and into the System 2 cognitive process that better enables logical thought. ${ }^{138}$ Durable evidence also better enables instructors to explain grading decisions in response to student inquiries.

Rubrics for grading student performance in online discussion boards can be rudimentary or sophisticated. Rubrics are commonly used in grading in law school classes, but are capable of greater nuance when applied to assignments that create durable evidence for careful instructor evaluation. W ritten assignments,

LIBR. INFO. SCI. 198, 201-02 (2011).

134. Consider, for example, any number of scenes from THE PAPER CHASE (20th Century Fox 1973).

135. Anecdotal evidence suggests that in the case of such a complaint, many law schools would defer to the instructor, except in the case of profound evidence of bad conduct. If bias or randomness actually is occurring, such deference should be intolerable.

136. See Rubrics, InSt. FOR L. TEACHING \& LEARNING, http://lawteaching.org/teaching/ assessment/rubrics/ [http://perma.cc/4NHZ-R4JY ] (last visited Sept. 29, 2015).

137. Course designers frequently use the term "artifact." As a lawyer, I prefer "evidence."

138. See generally Daniel Kahneman, Thinking Fast And Slow 20-22 (2011). 
like online discussion boards, permit fuller explanation to students of their task in earning grades than is possible in the case of rapid-fire, in-class discussions.

Here is an example of a rudimentary discussion board rubric that I employed from CICL:

Class discussions are integral to all law school classes, but all the more so when we are meeting exclusively online. We will have more, not less, interaction in this class than you experience in your live classes. To enforce this I will grade class discussions on a three-point scale as follows:

0 points: non-participation or throw-away responses. Continuing with our running example: "Monopoly power is important for antitrust" is a throw-away response. "I agree with Joe and Sally" is a throw-away response. "Everything has been said" is both (1) always false and (2) a throw-away response worth no points.

1 point: a valid, well-articulated point that nonetheless fails to advance the discussion very far. "Some form of conduct is required for a monopolist to violate the Sherman Act, see Microsoft Opinion at [XX]" is a good, and valid, response, but it should be more fully articulated.

It is also possible (if tragic) to earn 1 point by making an excellent and well-developed response but drafting it badly. Example of this: "m was a monopoly so got in trouble when they told customers not to deal with netscape. exclusion violates section 2 but monopoly does not b/c conduct is required. still need to know if conduct was harmful or neutral; just doing it not enough."

2 points: a valid, well-articulated point that carries out the thought to a logical conclusion. Because rarely is there only one conclusion to draw, such a contribution should recognize places in which more information is necessary definitively to reach a conclusion. The 2-point response cites authority as relevant while recognizing the limits of that authority. "The court of appeals in Microsoft would require [XX] (Opinion at [YY]), but that does not control the rule for Section 2 liability in most of the country." It also engages prior contributions as well as the opening discussion questions. The 2-point response is thorough and wellwritten. $^{139}$

A more sophisticated example of a discussion rubric developed from a colleague's draft for a Contract Drafting course is reproduced below: ${ }^{140}$

139. The CICL course syllabus is available upon request from the author.

140. Thanks to Professor Cynthia Adams for sharing materials that inspired this version of a discussion board rubric. 


\begin{tabular}{|c|c|c|c|c|}
\hline & 5 points & 3 points & 1 point & 0 p oints \\
\hline 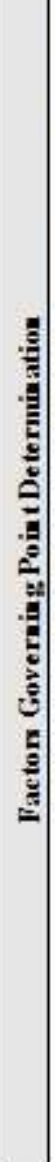 & $\begin{array}{l}\text { - Meets the } \\
\text { requirements for } 3 \\
\text { points } \\
\text { - Shows critical } \\
\text { thinking on } \\
\text { assignments } \\
\text { - Critiques issves } \\
\text { - Contribution is } \\
\text { innovative } \\
\text { - Stimulates } \\
\text { discussion, which } \\
\text { may include } \\
\text { offering a logical } \\
\text { divergent view point } \\
\text { or challenge } \\
\text { Elegant } \\
\text { draftsmanship } \\
\text { Respectfully } \\
\text { encovrages critical } \\
\text { thinking by peers } \\
\text { Post demons trates } \\
\text { critical analysis of } \\
\text { peers' contributions }\end{array}$ & $\begin{array}{l}\text { - Meets the } \\
\text { requirements for } \\
\text { - point } \\
\text { - Shows reflection } \\
\text { on assignments } \\
\text { - Related to topic } \\
\text { - Analyzes issues } \\
\text { - Contribution is } \\
\text { unique on } \\
\text { discussion forum } \\
\text { Provides } \\
\text { authorities or } \\
\text { reasons for } \\
\text { arguments } \\
\text { No obvious } \\
\text { drafting, } \\
\text { punctuation, } \\
\text { grammar, } \\
\text { spelling, diction } \\
\text { errors } \\
\text { Attempts to } \\
\text { present relevant } \\
\text { vew points for } \\
\text { consideration by } \\
\text { peers } \\
\text { Posts early and } \\
\text { follow s up } \\
\text { dests } \\
\text { reading and } \\
\text { reflection on } \\
\text { peers' } \\
\text { contributions }\end{array}$ & $\begin{array}{l}\text { - Shows } \\
\text { completion of } \\
\text { assignments } \\
\text { - Describes issues } \\
\text { - Provides } \\
\text { authorities in } \\
\text { support } \\
\text { - Does not relate } \\
\text { to or build on } \\
\text { prior comments } \\
\text { Limited } \\
\text { contributions to } \\
\text { board, does not } \\
\text { return to } \\
\text { advance } \\
\text { discussion } \\
\text { following a post } \\
\text { Drafting errors } \\
\text { in punctuation, } \\
\text { grammar, } \\
\text { spelling, or } \\
\text { diction } \\
\text { Last-mimte } \\
\text { posts }\end{array}$ & $\begin{array}{l}\text { - Shows a failure to } \\
\text { complete the } \\
\text { assignments } \\
\text { - Misstates or } \\
\text { misdescribes } \\
\text { issues } \\
\text { - Off-topic posts } \\
\text { - Offers no or poor } \\
\text { support or } \\
\text { rationale for } \\
\text { statements } \\
\text { Poor grammar and } \\
\text { punctuation, } \\
\text { including text- } \\
\text { speak (v no;)) } \\
\text { Makes short or } \\
\text { irrelevant remarks, } \\
\text { including 'I } \\
\text { agree" or "me too" } \\
\text { posts } \\
\text { Disrespectfil to } \\
\text { postings by peers } \\
\text { Fails to post as } \\
\text { required }\end{array}$ \\
\hline
\end{tabular}

In sum, asynchronous online discussion boards accomplish the interactivity goals of law school classes as well as, or better than, live classes. The discussion boards permit fuller and broader student participation, create artifacts for student review and instructor evaluation, and allow for more careful instructor assessment of student performance.

\section{Formative Assessment Strategy: Quizzes}

Some form of quizzing to evaluate student comprehension is not uncommon in live law school classrooms. Socratic dialogue is one means to evaluate comprehension. ${ }^{141}$ End-of-unit quizzes and midterms, whether graded or not, are

141. See Fines, supra note 22, at 4. 
increasingly common in live law-school teaching. ${ }^{142}$

The new ABA Standards specifically direct law schools to find ways to increase the use of "formative assessments" in the J.D. program: "[a] law school shall utilize both formative and summative assessment methods in its curriculum to measure and improve student learning and provide meaningful feedback to students." ${ }^{143}$ Although the Standards clarify that not every class needs to include both summative and formative assessments, it is generally understood among law school faculty and administrators that an increase in formative assessment exercises in individual law school classes is part of the ABA's goal with the revised Standards.

In synchronous course design, whether live or online, some amount of formative assessment occurs in the professor-student exchange. Professors can evaluate student comprehension through questioning and more subtly (but less robustly) through visual cues such as eye contact and nodding. Professors can communicate their assessment to students with comments or grades related to class participation.

In asynchronous course design, professors and students are by definition not participating in the course at the same time. Such real time visual and audial clues are therefore missing. Instead, evaluating student progress requires the creation of durable evidence of success in class that can then be evaluated both for grading purposes and for providing feedback to students. One effective source of evidence is a series of low-value quizzes that require students to complete class assignments in order to succeed, but are insufficiently low value that students are not unduly distracted from their longer-term study obligations.

The CICL course presented a particular concern because the primary assessment method for the course was a final paper and students were asked to concentrate much of their energies on drafting a paper covering a narrow subtopic within the general competition law field. Class exercises like discussion boards provided one solution to ensuring student attention to weekly assignments, but discussion board posts are also narrow in relation to a larger reading assignment.

Low-point-value quizzes proved to offer the perfect solution. On a weekly basis, students completed quizzes with a variety of multiple choice, true-false, matching, and short answer questions. Most of the questions were amenable to computerized grading and instant feedback to students. The point values were great enough to encourage the students to complete the quizzes and seek high

142. See, e.g., The Ungraded Midterm, PrawfsBlawg (Apr. 1, 2009), http://prawfsblawg. blogs.com/prawfsblawg/2009/04/the-ungraded-midterm.html [http://perma.cc/SS4N-E5W4] (midterms); Suzanne Sherry, Comment on A Law School Midterm Week: Hell Week or a Helluva Good Idea?, PrawfsBlawg (Mar. 11, 2010), available at http://prawfsblawg.blogs.com/ prawfsblawg/2010/03/when-i-guest-blogged-here-last-april-i-did-a-post-aboutlaw-school-midtermsi-noted-that-i-give-an-ungraded-midterm-in-all-o.html, [http://perma.cc/Z73C-URWS ] (unit quizzes).

143. AM. BAR Ass'N, supra note 6, at 23 (discussing Standard 314). An interpretation to Standard 314 clarifies that not every class is required to implement formative assessments. Id. 
scores but low enough not to distract students from other classwork and class preparation obligations. Quizzes provided opportunity for professor-student interaction as I followed up to correct misimpressions students received in their preparation. Of the many carefully scripted design elements in the spring 2015 presentation of CICL, students cited the low-value quizzes, and subsequent faculty-student interaction, as one of the most effective at promoting their comprehension of the course material.

Pedagogical innovations that faculty are beginning to graft onto their teaching in live classes-quizzes or other sorts of formative assessments-are natural elements of course design in an asynchronous online class. Increasing use of online classes with natural design elements that include formative assessments designed to monitor and to improve student achievement of learning outcomes will help to satisfy the ABA's revised Standards for accreditation.

\section{CONCLUSION}

The dominant pedagogical approach in U.S. law schools remains live teaching using a Socratic dialogue to understand and to generalize from the facts of individual cases. Recent challenges to that pedagogy as failing to produce relevant outcomes combine with student demand for innovative teaching to create an opening for online teaching in law schools. Evidence suggests that online teaching can improve learning outcomes while satisfying student demand and meeting changed ABA requirements for appropriate pedagogy in the J.D. degree.

Schools are moving to meet that demand. A substantial and increasing number of schools are offering courses online in their J.D. programs. Online teaching in law schools is on its way to being common in non-J.D. programs, including L.L.M. and M.J. degrees. Operating under a variance from AB A limits, one school has a J.D. program offered approximately half online. Reasons exist to believe the ABA will relax its restrictions and open the door to increased online courses.

McKinney Law Online, working in partnership and with the support of Indiana University and institutional partners CTL and eDS, is pursuing an aggressive agenda to offer an innovative and pedagogically robust program of online education. The law school is committed to increasing opportunities for current and potential students to pursue their courses and degrees in ways that best serve their needs and best respect the challenges of law school for a diverse array of students. Evidence suggests the innovations will improve our students' educational outcomes while reducing their costs. It is fair to expect that in coming years law schools across the United States will employ similar innovations. 